\title{
A PERSPECTIVA HABERMASIANA NA INVESTIGAÇÃO CIENTÍFICA: CONSIDERAÇÕES INICIAIS
}

\author{
Julieta Beatriz Ramos Desaulniers*
}

\begin{abstract}
SÍNTESE - Destaca-se o significado da teoria geral - como a perspectiva habermasiana à produção dos saberes científicos, que tem o seu aprimoramento garantido pela pesquisa.
\end{abstract}

ABSTRACT - We point out the meaning and the importance of the general theories - such as the habermasian perspective - for the improvement of scientific knowledge, which is accomplished through research.

A ciência evolui através da retificação instaurada pela pesquisa. Esse processo tem como pressuposto a estreita vinculação entre teoria e pesquisa. E mais; é indispensável para se questionar ou interdizer radicalmente as conclusões de uma teoria, que a experiência (a pesquisa) apresente as razões de sua oposição. ${ }^{1} \mathrm{Ou}$ seja, a retificação e o conseqüente avanço do conhecimento científico que se produzem através da pesquisa, estão diretamente associados com a qualidade e a competência com que se realiza $o$ ato de investigar.

Nesse sentido, o novo espírito científico propõe que se articule o racional e o real através da construção do objeto de estudo e, assim, transforma-se o objeto social em objeto científico. Sendo que o "vetor epistemológico", conforme essa perspectiva, vai do racional ao real, tal empreendimento supõe a elaboração de um projeto bem estudado a partir de uma teoria geral, ${ }^{2}$ que vai embasar o sistema de hipóteses - os juízos sintéticos "a priori" ${ }^{3}$ - que integra a problemática da pesquisa.

Assim, no mundo científico, "a meditação do objeto por parte do sujeito assume sempre a forma de projeto", em que se materializa a teoria escolhida em métodos, técnicas e procedimentos que constitui o instrumento capaz de instigar/destrinchar o fenômeno (enquanto uma teia de relações) e as suas circunstâncias, as quais estão naturalmente baralhadas.

\footnotetext{
* Pontificia Universidade Católica do Rio Grande do Sul, PUCRS.

1 BACHELARD, Gaston. O novo espírito cientifico. Lisboa: Edições 70, 1986. p. 16.

2 Idem, p. 14.

3 Idem, p. 100.
}

\begin{tabular}{|l|l|l|l|l|l|}
\hline VERITAS & Porto Alegre & v. 41 & $\mathrm{n}^{0}$ 162 & Junho 1996 & p. 279-280 \\
\hline
\end{tabular}


De acordo com esse enfoque, demonstra-se o real, não se mostra o mesmo, 0 que supõe a utilização de múltiplos métodos para se apreender o mais possível a complexidade do objeto, já que é ele quem fornece os elementos à prova - um dos momentos em que é possivel mensurar o grau de "realização do racional". ${ }^{4}$

Todo esse empreendimento, que envolve a experiência científica enquanto uma "razão confirmada", necessita de uma vigorosa revisão da literatura, a fim de introduzir o tema escolhido - e o sistema de relações que o caracteriza enquanto objeto científico - no âmbito de um debate teórico/científico. Somente assim, é possível verificar se a investigação desenvolvida recua, repete, avança ou estabelece algumas rupturas importantes em relação às pesquisas/ao conhecimente científico produzidos anteriormente. ${ }^{5}$

Ainda, somente 0 embate desencadeado entre o racional e 0 real em novos contextos é capaz de relativizar categorias e/ou referenciais teóricos, como o de Habermas, construídos em realidades culturais específicas e, ao mesmo tempo, ampliar o "fôlego" de tais referenciais. Esse é o interesse e a busca dos estudos e pesquisas a serem expostos a seguir.

4 Idem, p. 13.

5 MARRE, Jacques Léon. "História de vida e método biográfico". In: Cademos de Sociologia. Porto Alegre: Ed. UFRGS, v. 3, n. 3, 1991. 